International Journal of Social Science and Economic Research

ISSN: 2455-8834

Volume:06, Issue:07 "July 2021"

\title{
STATUS OF EDUCATION AND EMPLOYMENT OF MUSLIMS IN INDIA
}

\author{
Mashkoor Ahmad ${ }^{1}$ and Khalid Khan ${ }^{2}$ \\ ${ }^{1}$ Assistant Professor, Department of Geography, Aligarh Muslim University, Aligarh \\ ${ }^{2}$ Assistant Professor, Indian Institute of Dalit Studies, New Delhi
}

DOI: 10.46609/IJSSER.2021.v06i07.040 URL: https://doi.org/10.46609/IJSSER.2021.v06i07.040

\begin{abstract}
Muslims constitute the second largest religious group and the largest religious minority of India. According to Sachar Committee Report (2006) of government of India, Muslims have been found socio-economically one of most backward communities of the country. In politics too Muslims have remained under represented at both the national and state levels. On the recommendations of Sachar Committee report the government of India has started many welfare schemes for the upliftment of Muslims and other minorities. But literature review suggests that still the socio-economic conditions of Muslims remained very unsatisfactory. For the inclusive deployment of the country it is essential that all the religious communities enjoy the equal access to different opportunities including employment, education, politics, health, housing safe drinking water and social security well. The present paper therefore examines the status of education and employment of Muslims vis-à-vis other religious groups in India. Different indicators of education and employment such as literacy rate, level of education, share in higher education, gross attendance ratio in school and higher education, dropout rates, reasons of dropout, mean years of schooling, work participation rate, share of salaried workers by type of enterprises have been analysed to see the status of Muslims compared to other religious groups in India. The study is based on secondary data obtained from National Sample Survey Organisation (NSSO) and $64^{\text {th }}$ round, 2007-08 and $68^{\text {th }}$ Round, 2011-12. Simple statistical and descriptive methods have been employed for analyzing the data. The results show that huge inequalities have been observed in various indicators of education like literacy rate, educational attainment, dropout rates, reasons for drop out and mean years of schooling etc. Besides, disparities are also visible across the religious communities in the work participation rate as well as in the distribution of salaried workers in private and government sectors.
\end{abstract}

Key Words: Education, Employment, Muslims, Literacy 
International Journal of Social Science and Economic Research

ISSN: 2455-8834

Volume:06, Issue:07 "July 2021"

\section{Introduction}

The Muslims minorities-the largest religious minority remained the most underdeveloped and backward almost in all parameters of human development. They perform low in the dimension of employment, literacy rate, educational attainment, access to health, safe drinking water, sanitation, housing, ownership to land, resources, as well as access to justice as well as political voice etc. This study investigates the status of Muslims in terms of the various indicators of education and employment. Education is one of the most significant indicators of human development and it is associated with a large number of other socio-economic variables such as poverty, employment, unemployment, health, and awareness about different phenomena. The existing evidence shows that disparities exist in various indicators of education across the religions in India. Recently various studies at national and regional level have revealed that Muslims are the most backward religious community with respect to almost all the parameters of education. Similarly condition of employment is also unsatisfactory for Muslims. The quality of job is low among them and hence earning is also very low leading to higher poverty level among them. This paper discusses these two aspects of development based on the national sample survey on education, $64^{\text {th }}$ round 2007-08 and employment-unemployment, $68^{\text {th }}$ round, 2011-12.

\section{Status of Education among Muslims vis-à-vis Other Religious Communities}

This section examines the inequalities in literacy rate, educational attainment, mean years of schooling, out of school children as well as reasons for discontinuation or drop out and mean year of schooling among the religious communities in India.

\section{Literacy Rate}

Religion-wise literacy rate for the population 7 years and above has been demonstrated in Fig. 1. It is seen that as per the NSS $68^{\text {th }}$ round 2011-12, the average literacy rate (i.e.was not able to read or write with understanding)in India was 75.0 percent. However, significant inequalities exist in the literacy rates across religious communities in country as the literacy rate varied from the highest of 87.4 percent for Christians to the lowest of 71.6 percent for Muslims. While the literacy rate of Hindus-the majority community was equal to the national average of 75.0 percent. The literacy rate of all the religious minorities except Muslims was above the national average.The low literacy rate among Muslims is a matter of serious concern, it is therefore suggested that efforts should be made to increase the level of literacy among Muslims in particular and among all the population in general so as to improve the literacy rate and minimize the inequalities in the literacy rate among various religious communities in the country. 
International Journal of Social Science and Economic Research

ISSN: 2455-8834

Volume:06, Issue:07 "July 2021"

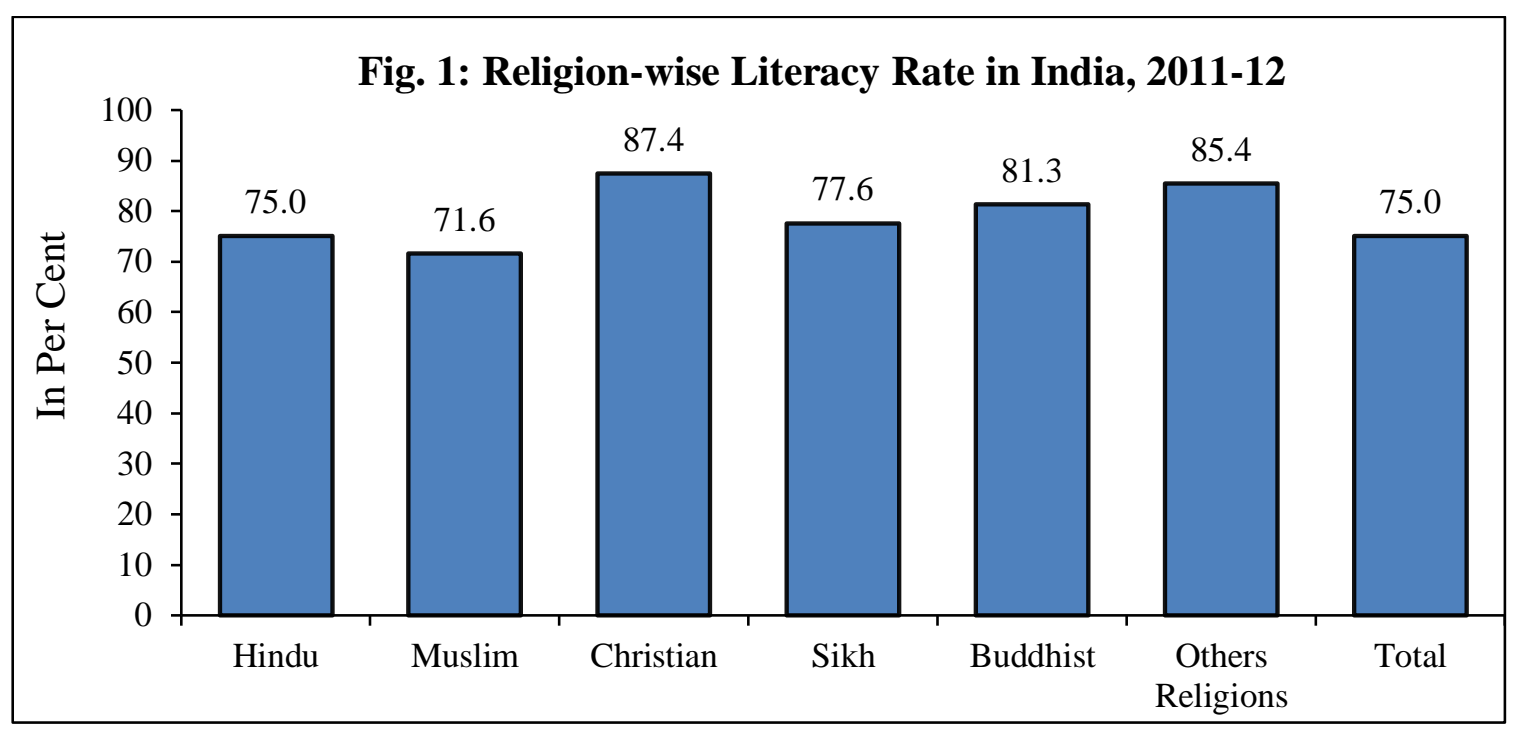

Source: Calculations based on the NSS employment and unemployment Survey, $68^{\text {th }}$ round.

As per the NSSO $68^{\text {th }}$ round (2011-12) in India 75.0 percent of the population (7 years and above) was literate, however, disparities in the literacy rates were quite visible across religions in the country. With 71.6 percent, Muslims represented the lowest literacy rate in the country and it is the only religious group having literacy below the national average. Among all other religions the literacy rate was above the national average and the highest being for Christians (87.4 percent). While literacy rate of Hindus was equal to the national average (75 percent).

Further, it is to be seen that literacy rate among various religious communities varied by quintile groups. The literacy rate increases as we move upward across the quintile group. The literacy rate was low in lower quintile groups across all the religions and higher in higher quintile groups. In the lowest quintile group the literacy rate was as low as 66.7 percent on the contrary in the highest quintile group the literacy rate was as high as 83.5 percent. Muslims represented the lowest literacy rate almost in all the quintile groups as compared to all religious groups in the country. In the lowest quintile group the literacy was the highest among Buddhists (78.7 percent) while in the highest quintile group the literacy rate was 94.5 percent among Christians, 93.7 percent among other religions, 85.6 percent among Buddhists and only 78.5 percent among Muslims. Thus, it is seen that as far as the literacy by quintile group is concerned the conditions of Muslims was very unsatisfactory. Therefore, special efforts should be done to increase the literacy among disadvantaged minorities especially Muslims so as to bring them to the mainstream population in the country. 
International Journal of Social Science and Economic Research

ISSN: 2455-8834

Volume:06, Issue:07 "July 2021"

Table 1: Literacy Rate across Religious Communities by Quintile Groups in India(In Percent), 2011-12

\begin{tabular}{|c|c|c|c|c|c|c|}
\hline \multirow{2}{*}{$\begin{array}{c}\text { Religious } \\
\text { Community }\end{array}$} & \multicolumn{6}{|c|}{ Quintile Group } \\
\cline { 2 - 6 } & $0-20$ & $20-40$ & $40-60$ & $60-80$ & $80-100$ & Total \\
\hline Hindu & 66.7 & 71.6 & 74.1 & 77.8 & 83.4 & 75.0 \\
\hline Muslim & 64.6 & 71.1 & 72.2 & 75.1 & 78.5 & 71.6 \\
\hline Christian & 77.7 & 83.6 & 85.3 & 91.2 & 94.5 & 87.4 \\
\hline Sikh & 64.7 & 71.0 & 76.7 & 79.5 & 87.2 & 77.6 \\
\hline Buddhist & 78.7 & 75.1 & 84.8 & 85.8 & 85.6 & 81.3 \\
\hline Others & 70.9 & 70.2 & 85.0 & 89.5 & 93.7 & 85.4 \\
\hline Total & 66.7 & 71.7 & 74.2 & 78.0 & 83.5 & 75.0 \\
\hline
\end{tabular}

Source: Calculations based on the NSS Employment and Unemployment Survey, $68^{\text {th }}$ Round.

\section{Levels of Education}

Education has been universally accepted as the most significant means for social and economic transformation. A well educated population, adequately equipped with knowledge and skill not only helps economic growth, but is also an important precondition for inclusive growth and development because it is the educated and skilled population which is benefitted most from the employment opportunities (Planning Commission, 2011). The level of education has very clear consequences upon different economic and social indicators of development like employment, poverty, health etc. Panagariyet.al. (2013)observed that higher level of education of the head of household is associated with low level of poverty and in rural areas also, rising education level of the household head is related with sharply declining poverty rates. Thus, high prevalence of poverty among some of the socio-religious communities like as Muslims, Buddhists, may be attributed to low level of education among them.

The education level of 17.2 percent of the population was below primary level. Primary and middle education level each accounted around 16 percent of the population in the country. Slightly more than one-tenth of the population was having secondary level education. Very sharp disparities have been observed in the education level across the religions in India. The percentage of population with the lowest education level was the highest among Muslims. As high as 21.0 percent of Muslim population was literate below primary level in comparison to 16.8 percent for Hindus, 15.0 percent for other religions, 14.3 percent for Christians. The percentage of population with primary education was found very high among Buddhists (18.9 
International Journal of Social Science and Economic Research

ISSN: 2455-8834

Volume:06, Issue:07 "July 2021"

percent) and Muslims (18.1 percent), Hindus (15.3 percent) and the lowest among other religions (13.3 percent). The secondary and higher secondary education was the lowest among Muslims. Thus, a very high proportion of population of Muslims remained educated below higher secondary. With only 0.6 percent the proportion of diploma holders was also the lowest among Muslims while it was as high as 3.4 percent for Christians and 1.0 percent for Hindus. Again the percentage of education level with graduate and above was the lowest among Muslims (3.2 percent), as compared 7.2 percent for Hindus, 11.1 percent for Christians and 17.9 percent for other religions. Thus, level of education was the worst among Muslim as majority of them having the lowest level of education.

Table 2: Religion-wise Population (7 years and above) by Level of Education (In Percent), 2011-12

\begin{tabular}{|c|c|c|c|c|c|c|c|}
\hline \multirow{2}{*}{$\begin{array}{c}\text { Educational } \\
\text { Attainment }\end{array}$} & \multicolumn{7}{|c|}{ Religious Community } \\
\cline { 2 - 8 } & Hindu & Muslim & Christian & Sikh & Buddhist & others & Total \\
\hline Illiterate & 25.0 & 28.4 & 12.6 & 22.4 & 18.7 & 14.6 & 25.0 \\
\hline Below primary & 16.8 & 21.0 & 14.3 & 12.3 & 13.1 & 15.0 & 17.2 \\
\hline Primary & 15.3 & 18.1 & 17.0 & 17.5 & 18.9 & 13.3 & 15.8 \\
\hline Middle & 15.8 & 14.9 & 18.5 & 12.7 & 18.5 & 12.9 & 15.7 \\
\hline Secondary & 11.5 & 9.1 & 13.9 & 16.6 & 14.2 & 14.0 & 11.3 \\
\hline Higher secondary & 7.4 & 4.7 & 9.3 & 10.5 & 10.3 & 11.0 & 7.2 \\
\hline Diploma & 1.0 & 0.6 & 3.4 & 0.7 & 1.0 & 1.3 & 1.0 \\
\hline Graduate above & 7.2 & 3.2 & 11.1 & 7.2 & 5.4 & 17.9 & 6.8 \\
\hline Total & 100 & 100 & 100 & 100 & 100 & 100 & 100 \\
\hline
\end{tabular}

Source: Calculations based on the NSS Employment and Unemployment Survey, $68^{\text {th }}$ Round.

\section{Gross Attendance Ratio in School Education}

Though during the last few years many scholarship schemes have been started for the students belonging to religious minorities and other disadvantaged groups in India, yet some of them still are lagging as far as their access to education is concerned. The poor economic background is one reason for this state of affairs. The direct and indirect discrimination of minorities generally their equal access to education which is reflected by inadequate funding, resources, schools etc. in minority dominated areas of the country (UNDP, 2010). 
International Journal of Social Science and Economic Research

ISSN: 2455-8834

Volume:06, Issue:07 "July 2021"

Gross attendance ratio has been measured as percentage of students attending an educational level irrespective of age to corresponding age group population. The value of gross attendance ratio for different education level reveals that huge inequalities exist across religions in India. Among all the religion, Muslims suffer the most as far as their access to education at various levels is concerned. The gross attendance ratio at all level is low for Muslims as compared to all other religious communities. Table 3 reveals that disparities in gross attendance ratio at different levels of education are pervasive across religions. Up to primary level the gross attendance ratio was the highest among Sikhs (113.1 percent) followed by Hindus (105) while Muslims (98.1 percent) had the lowest attendance ratio at this level. At middle level the gross attendance ratio was the highest among other religions (103.4 percent) followed by Christians (102.7 percent), and Buddhists (101.0 percent) and Sikhs (95.7 percent), while the lowest was found among Muslims (88.3 percent). Huge disparities were found in gross attendance ratio at secondary and higher secondary level. At secondary level the gross attendance ratio was highest among Buddhists (131.5 percent), Sikhs (103.7 percent) while Muslims with only 80.0 percent had the lowest gross attendance ratio among the religious communities. Similarly, at higher secondary level also the lowest gross attendance ratio was recorded among Muslims (51.8 percent) compared to 83.4 percent among Christians, and 73.3 percent among Hindus. Thus, the conditions of Muslims were the most disappointing across the religious communities in the country. Therefore, seeing the present conditions of Muslims in gross attendance ration it is advisable that special effort should be made to have their access to the education at various levels so as to bring them to the main stream population in India.

During the last few years, the scholarship schemes for religious minorities and other disadvantaged groups have enabled many students from these communities to continue their education. However, greater effort is needed to improve enrollment ratios and to reduce dropout rates among minorities (Planning commission of India, 2011) especially among Muslim community which suffers from highest illiteracy in the country.

Table 3: Gross Attendance Ratio (In Percent) across Religious Communities in India, 201112

\begin{tabular}{|c|c|c|c|c|}
\hline \multirow{2}{*}{$\begin{array}{c}\text { Religious } \\
\text { Community }\end{array}$} & \multicolumn{4}{|c|}{ Level of Education } \\
\cline { 2 - 5 } & Up to Primary & Middle & Secondary & Higher Secondary \\
\hline Hindu & 105.1 & 96.2 & 94.6 & 73.3 \\
\hline
\end{tabular}


International Journal of Social Science and Economic Research

ISSN: 2455-8834

Volume:06, Issue:07 "July 2021"

\begin{tabular}{|c|c|c|c|c|}
\hline Muslim & 98.1 & 88.3 & 80.0 & 51.8 \\
\hline Christian & 98.2 & 102.7 & 100.9 & 83.4 \\
\hline Sikh & 113.1 & 95.7 & 103.7 & 68.6 \\
\hline Buddhist & 99.4 & 101.0 & 131.5 & 67.2 \\
\hline Others & 104.3 & 103.4 & 86.3 & 67.1 \\
\hline Total & 103.9 & 95.2 & 92.8 & 70.0 \\
\hline
\end{tabular}

Source: Calculations based on the NSS Employment and Unemployment Survey, $68^{\text {th }}$ Round.

\section{Status of Higher Education}

\section{Gross Attendance Ratio in Higher Education}

In the present study the gross attendance ratio has been used to show the participation in higher education and has been calculated as the percentage of students in higher education to the population in the age group of 18-22 years. It is seen that in 2007-08, the gross attendance ratio in higher education was 17.2 percent with significant disparities between urban (30.2 percent) and rural (11.1 percent) areas. Similarly, disparities in gross attendance ratio by religions were also very pronounced and thus are a matter of concern for Muslims who have very low gross attendance ratio in higher education. With only 9.5 percent gross attendance ratio, Muslims were very much below the national average of 17.2 percent while gross attendance ratio of Christians was 29.0 percent followed by others (27.6 percent), Buddhists (20.2 percent), Hindus (18.3 percent) and Sikhs 9.5 percent. Likewise, glaring disparities were found by gender across the religious groups in both the rural and urban areas of the country.

Table 4: Gross Attendance Ratio by Religious Communities in India (In Percent), 2007-08

\begin{tabular}{|c|l|c|c|c|c|c|c|c|}
\hline \multirow{2}{*}{ Area } & \multirow{2}{*}{ Sex } & \multicolumn{7}{|c|}{ Religious Community } \\
\cline { 3 - 9 } & & Hindu & Muslim & Christian & Sikh & Buddhist & Others & Total \\
\hline \multirow{3}{*}{ Rural } & Male & 14.5 & 8.3 & 20.6 & 9.1 & 11.1 & 9.8 & 13.7 \\
\cline { 2 - 9 } & Female & 8.4 & 4.9 & 21.1 & 11.7 & 8.9 & 6.3 & 8.3 \\
\cline { 2 - 9 } & Total & 11.6 & 6.6 & 20.8 & 10.3 & 10.0 & 7.9 & 11.1 \\
\hline \multirow{2}{*}{ Urban } & Male & 33.5 & 15.1 & 35.7 & 28.2 & 21.7 & 45.3 & 29.8 \\
\cline { 2 - 9 }
\end{tabular}


International Journal of Social Science and Economic Research

ISSN: 2455-8834

Volume:06, Issue:07 "July 2021"

\begin{tabular}{|l|l|l|l|l|l|l|l|l|}
\multirow{5}{*}{ Total } & Female & 34.3 & 11.4 & 44.0 & 46.6 & 42.3 & 60.9 & 30.6 \\
\cline { 2 - 9 } & Total & 33.8 & 13.5 & 40.2 & 36.3 & 31.4 & 52.7 & 30.2 \\
\hline \multirow{3}{*}{} & Male & 20.4 & 11.4 & 26.5 & 13.9 & 16.3 & 26.5 & 19.1 \\
\cline { 2 - 9 } & Female & 16.0 & 7.5 & 31.3 & 19.5 & 24.2 & 28.8 & 15.2 \\
\cline { 2 - 9 } & Total & 18.3 & 9.5 & 29.0 & 16.5 & 20.2 & 27.6 & 17.2 \\
\hline
\end{tabular}

Source: Calculations based on the NSS 64th Round, 2007-08

In rural areas the highest gross attendance ratio was found among Christians (20.8 percent) while the lowest among Muslims. In urban areas the highest gross attendance ratio was reported among others religions (52.7 percent) while it was the lowest among Muslims (13.5 percent). In rural areas, gross attendance ratio for females (8.3 percent) was lower compared to males (13.7 percent) on the other hand in urban areas gross attendance ratio for female (30.6 percent) is slightly higher as compared to males (29.8 percent). The high cost associated with higher education was an important deterrent to participation in higher education among Muslims characterised by high incidence of poverty. The low participation of Muslims in higher education may adversely affect their employability in terms of quality of jobs. In fact, high incidence of poverty and low participation in higher education feed on each other (India Human Development Report 2011).

\section{Share of Population in Higher Education}

As per the NSS $64^{\text {th }}$ round (2007-08), in India, 4.4 percent of the total population was graduate and above. However, significant disparities were noticed in share of graduate and above by age group and religion. The share of graduate and above population to the total population varied from 10.3 percent for others religion followed by 6.8 percent for Christians, 5.2 percent for Sikhs, 4.7 percent for Hindus and 3.5 percent for Buddhists while for Muslims it was only 2 percent. Thus the share of graduate and above population to total population was the lowest among Muslims and it was less than half of the national average. Similarly, the share of graduate and above was the lowest among the Muslims in all 20 years and above age groups except for 40-49 years of age group in which the share of Buddhists was the lowest. Thus, share of graduate and above population among all the religious communities except Muslims and Buddhists was above the national average. Therefore, emphasis should be given to increase the participation of Muslims and Buddhists in higher education so as to bring them to the mainstream population in the country. 
International Journal of Social Science and Economic Research

ISSN: 2455-8834

Volume:06, Issue:07 "July 2021"

Table 5: Share of Graduate and above to total Population by Age Group across Religious Communities (In Percent), 2007-08

\begin{tabular}{|c|c|c|c|c|c|c|c|}
\hline \multirow{2}{*}{$\begin{array}{c}\text { Age group } \\
\text { In years }\end{array}$} & \multicolumn{7}{|c|}{ Religious Community } \\
\cline { 2 - 8 } & Hindu & Muslim & Christian & Sikh & Buddhist & Others & Total \\
\hline$<20$ & 0.0 & 0.0 & 0.0 & 0.1 & 0.0 & 0.0 & 0.0 \\
\hline $20-29$ & 10.4 & 4.8 & 14.5 & 10.3 & 9.1 & 20.8 & 9.8 \\
\hline $30-39$ & 8.9 & 3.9 & 11.8 & 9.4 & 7.5 & 17.9 & 8.5 \\
\hline $40-49$ & 7.4 & 3.6 & 10.5 & 7.3 & 2.3 & 17.8 & 7.1 \\
\hline $50+$ & 4.9 & 2.5 & 6.3 & 6.0 & 2.6 & 9.2 & 4.8 \\
\hline Total & 4.7 & 2.0 & 6.8 & 5.2 & 3.5 & 10.3 & 4.4 \\
\hline
\end{tabular}

Source: Calculations based on the NSS $64^{\text {th }}$ Round, 2007-08.

\section{Students in Higher Education by Type of Institutions}

It is seen from Table6 that around 46 percent of the total students in higher education were enrolled in government institutions. The percentage of students among Sikhs (56.7 percent), Buddhists (53.7 percent), Muslims (47.6 percent) and Hindus (46.7 percent) was above the national average which indicates that due to lack of money or awareness about quality of education these communities enroll their children in government institutions most of which do not impart good quality education. On the other hand the proportion of students in government institution was below the national average among Christians and other religions. It should be noted here that among Hindus a relatively higher share of students in government institution may be attributed to the higher share of scheduled caste and scheduled tribe students who represent the poorest section of Hindu community. In private added institutions the percentage of Muslim students was the lowest while it was the highest among other religions followed by Buddhists.

Table 6: Distribution of Students in Higher Education by Institution type and Religion in India (In Percent) 2007-08

\begin{tabular}{|l|c|c|c|c|c|c|c|}
\hline \multirow{2}{*}{$\begin{array}{l}\text { Type of } \\
\text { Institution }\end{array}$} & \multicolumn{7}{|c|}{ Religious Community } \\
\cline { 2 - 8 } & Hindu & Muslim & Christian & Sikh & Buddhist & Others & Total \\
\hline Government & 46.7 & 47.6 & 28.6 & 56.7 & 53.7 & 40.3 & 46.4 \\
\hline Local body & 1.2 & 1.1 & 0.5 & 0.9 & 0.0 & 0.2 & 1.1 \\
\hline Private aided & 29.0 & 27.1 & 28.1 & 27.5 & 35.7 & 36.2 & 28.9 \\
\hline
\end{tabular}


International Journal of Social Science and Economic Research

ISSN: 2455-8834

Volume:06, Issue:07 "July 2021"

\begin{tabular}{|l|c|c|c|c|c|c|c|}
\hline Private un-aided & 21.6 & 23.0 & 42.2 & 13.6 & 7.4 & 19.9 & 22.1 \\
\hline Not known & 1.5 & 1.2 & 0.6 & 1.2 & 3.2 & 3.5 & 1.4 \\
\hline Total & 100 & 100 & 100 & 100 & 100 & 100 & 100 \\
\hline
\end{tabular}

Source: Calculations based on NSS $64^{\text {th }}$ Round, 2007-08.

\section{Out of School Children}

It is very disappointing that in India around 19 percent of the children of age 6-17 years have either never attended school or have attended school in the past but are currently not attending and thus have been identified as out of school (India Human Development Report 2011). Surprisingly, very large variations have been reported in the proportion of out of school children across religions. In this regards Muslim children are the most vulnerable due to higher poverty, low education etc. Among Muslims around 29 percent of the children were out of school. Moreover the proportion of the out of school female children was as high as 31.5 percent. Among Sikhs and Hindus each 17.7 percent of children were found out of school. However, with only 9.7 percent of out of school children the situation was comparatively better among Christians. Among the out of school children, the proportion of female children remained higher compared to male children across all the religious communities in the country.

\section{Major Reasons for Discontinuation/ Drop out}

Though, there may be very many reasons for discontinuation or drop out of children from the schools but lack of interest among parents; and children as well as financial problems have emerged as the main reasons in the country. These three reasons accounted around half of the discontinuation or drop out cases in the country. The reasons for discontinuation or drop out varied across religious groups. Among Muslims 18 percent of the discontinuation or drop out was due to lack of interest of parents followed by Hindu (16 percent), Christians (10 percent) and Sikhs (9 percent). Financial constraints accounted highest proportion of discontinuation or drop out of children among all the religious communities especially Muslims (27 percent). Among Sikhs, financial constraints were responsible for 22 percent of the discontinuation or drop out, followed by Christians (20 percent) and Sikhs (20 percent). Lack of interest among the children emerged also one of the main reasons for discontinuation or drop out from the school. This reason accounted 20 percent of the discontinuation or drop out among Sikhs followed by Hindus (14 percent) and Christians (14 percent). Surprisingly, the lack of interest among children accounted for the lowest proportion of discontinuation or drop out among Muslim children (12 percent). 
International Journal of Social Science and Economic Research

ISSN: 2455-8834

Volume:06, Issue:07 "July 2021"

\section{Mean Years of Schooling}

Disparities have also been found mean years of schooling across the religious communities in the country. The India Human Development Report 2011revealed that mean years of schooling was only 4.2 years with sharp inequalities between rural (3.5 years) and urban (6.2 years) areas of the country. Thus, in addition to the considerable proportion of out of school children, it is also very disappointing that the mean years of schooling was also very low. They low mean years of schooling may adversely affect many aspects including employment and health. The lower mean year of schooling among the Muslim community may be attributed to higher level of poverty among them.

Furthermore, the inequalities in the mean years of schooling across religions revealed the concerns about educational conditions of some of the religious groups. The mean years of schooling was found to be the highest among Christians (5.7 years), followed by Sikhs (4.9 years) and Hindus (4.3 years) on the other hand Muslims recorded the lowest mean years of schooling (3.3 years). Similarly, inequalities in the mean years of schooling across religions remained contrasting in both the rural and urban areas. Muslims remained the most deprived in both the rural and urban areas as far as the mean years of schooling are concerned.

Table 7: Out of School Children (6-17 years), Major Reasons for Discontinuation/ Drop Out and Mean Years of Schooling (for age 7 years and above) by Major Religious Communities in India, 2007-08

\begin{tabular}{|l|c|c|c|c|c|c|c|c|c|}
\hline $\begin{array}{l}\text { Major } \\
\text { Religious } \\
\text { Communities }\end{array}$ & $\begin{array}{l}\text { Out of School Children } \\
\text { (6-17 years), 2007-08 } \\
\text { (In Percent) }\end{array}$ & \multicolumn{3}{|c|}{$\begin{array}{c}\text { Major Reason for Discontinuation/ Drop Out } \\
\text { 2007-08 (In Percent) }\end{array}$} & \multicolumn{3}{|c|}{$\begin{array}{c}\text { Mean Years of } \\
\text { Schooling (in the age } \\
\text { group 7 years and } \\
\text { above) }\end{array}$} \\
\cline { 2 - 11 } & Male & Female & Total & $\begin{array}{c}\text { Parents not } \\
\text { interested in Studies }\end{array}$ & $\begin{array}{c}\text { Financial } \\
\text { Constraints }\end{array}$ & $\begin{array}{c}\text { Child not } \\
\text { Interested }\end{array}$ & Rural & Urban & Total \\
\hline Hindu & 15.5 & 20.2 & 17.7 & 16 & 20 & 14 & 3.6 & 6.5 & 4.3 \\
\hline Muslim & 26.4 & 31.5 & 28.8 & 18 & 27 & 12 & 2.8 & 4.3 & 3.3 \\
\hline Christian & 8.7 & 10.7 & 9.7 & 10 & 20 & 14 & 5 & 7.2 & 5.7 \\
\hline Sikh & 15.3 & 20.9 & 17.7 & 9 & 22 & 20 & 4.2 & 7.3 & 4.9 \\
\hline
\end{tabular}

Source: NSS and $64^{\text {th }}$ Round 
International Journal of Social Science and Economic Research

ISSN: 2455-8834

Volume:06, Issue:07 "July 2021"

Note: Borrowed from India Human Development Report 2011: Towards Social Inclusion, Panning Commission, Government of India, pp. 192, 194 and195

\section{Status of Employment}

\section{Work Participation Rate}

The working population in the labour force has been used to calculate the work participation rate. The NSSO $68^{\text {th }}$ round (2011-12) revealed that in India the work participation rate was 38.4 percent. The rural work participation rate (39.8 percent) was higher as compared to urban work participation rate (35.3 percent). So far as the religion is concerned the highest work participation rate was found among Buddhists (45.0 percent) and the lowest among Muslims community (32.8 percent). A low work participation rate among Muslims community is mainly a result of very low economic participation of Muslim women, especially in urban areas of the country (Papola, 2012; Planning Commission, 2012). However, it is to be seen that contrasting variations were observed in the work participation by gender among different religious communities in the country. With 58.0 percent, the male work participation rate was the highest among other religious communities followed by Sikhs (56.3 percent) while the lowest male work participation rate was found among Muslims (51.1 percent). In case of female, the highest work participation rate was observed among Buddhists (34.2 percent) while the lowest among Muslims (13.4 percent). Thus, in the country the lowest work participation rate for both males and females was found among Muslims. Lower level of work participation rate among Muslims community shows that they have low access to different opportunities including public employment and business, good quality of education etc. compared to all other religious groups in the country (Shariff, 2013).

In rural areas the work participation rate varied from 50.2 percent for Buddhists to 32.8 percent for Muslims. Rural male work participation rate was the highest among other religions (57.9 percent) and the lowest among Muslims (49.8 percent). Similarly, in urban areas too, the male work participation rate was the highest among other religions ( 58 percent) followed by Hindus (54.9 percent) and Sikhs (54.7 percent). In urban areas, male work participation was 53.1 percent among Muslims while with 50.2 percent Buddhists represented the lowest work participation rate.

Table 8: Work Participation Rate (In Percent) by Religious Communities and Gender in India, 2011-12

\begin{tabular}{|c|c|c|c|}
\hline Religious & Rural & Urban & Total \\
\hline
\end{tabular}


International Journal of Social Science and Economic Research

ISSN: 2455-8834

Volume:06, Issue:07 "July 2021"

\begin{tabular}{|l|c|c|c|c|c|c|c|c|c|}
\hline Community & Male & Female & Total & Male & Female & Total & Male & Female & Total \\
\hline Hindu & 54.8 & 25.8 & 40.7 & 54.9 & 15.2 & 35.8 & 54.8 & 22.7 & 39.2 \\
\hline Muslim & 49.8 & 15.2 & 32.8 & 53.1 & 10.4 & 32.7 & 51.1 & 13.4 & 32.8 \\
\hline Christian & 53.6 & 28.7 & 41.2 & 54.0 & 24.8 & 39.0 & 53.7 & 27.1 & 40.3 \\
\hline Sikh & 56.9 & 25.7 & 42.2 & 54.7 & 12.8 & 34.8 & 56.3 & 22.3 & 40.2 \\
\hline Buddhist & 57.1 & 42.4 & 50.2 & 50.2 & 21.1 & 37.0 & 54.3 & 34.2 & 45.0 \\
\hline Others & 57.9 & 34.5 & 46.4 & 58.0 & 9.7 & 33.7 & 58.0 & 21.7 & 39.9 \\
\hline Total & 54.2 & 24.7 & 39.8 & 54.6 & 14.6 & 35.3 & 54.3 & 21.5 & 38.4 \\
\hline
\end{tabular}

Source: Calculations based on the NSS Employment and Unemployment Survey, $68^{\text {th }}$ Round.

\section{Regular Salaried Workers by Type of Enterprise}

The distribution of salaried works gives a very contrasting picture by religion and by type of enterprises. It is revealed from Table 9 that in India 70 percent of the salaried workers were engaged in private enterprises which are unorganised with limited or no social and economic security to the employees while only 30 percent were engaged in public enterprises which are considered as better paid and gives other social and economic benefits as well as securities to the employees. The data show that among Muslims as low as 17.2 percent salaried workers were engaged in government enterprises compared to 33.9 percent for Christians who enjoy very high literacy rate and higher educational status thereby leading to greater opportunities to enter the government enterprises.

Table 9: Distribution of Regular Salaried Worker by Type of Enterprise in India, 2011-12

\begin{tabular}{|c|c|c|c|}
\hline \multirow{2}{*}{ Religious Community } & \multicolumn{3}{|c|}{ Type of Enterprise } \\
\cline { 2 - 4 } & Public Enterprise & Private Enterprise & All \\
\hline Hindu & 31.4 & 68.6 & 100 \\
\hline Muslim & 17.2 & 82.8 & 100 \\
\hline Christian & 33.9 & 66.1 & 100 \\
\hline Sikh & 29.9 & 70.1 & 100 \\
\hline Buddhist & 33.6 & 66.4 & 100 \\
\hline Other Religions & 26.4 & 73.6 & 100 \\
\hline Total & 30.0 & 70.0 & 100 \\
\hline
\end{tabular}

Source: Calculations based on the NSS employment and unemployment Survey, $68^{\text {th }}$ round 


\section{International Journal of Social Science and Economic Research}

ISSN: $2455-8834$

Volume:06, Issue:07 "July 2021"

Among Buddhists a higher ratio of salaried workers (33.6) may be attributed to the reservation policies for scheduled castes (Dalits). Hindus were also having comparatively higher ratio of salaried workers in engaged in government enterprises. Muslims are largely engaged in the unorganized sector which shows their precarious situation. The Sachar Committee report (2006) report hasrevealed, that despite economic boom Muslims have to bear the brunt of the so called competitive forces unleashed by liberalization. Displacement of Muslims from traditional occupations has deprived them of their means of livelihood. Majority of the Muslims, are engaged in the unorganized sector of the economy which hardly enjoys protection of any kind and thus the adverse impact of liberalization has been more acute for them. Moreover many traditional occupations of Muslims in industries like silk and sericulture, hand and power looms, the leather industry, automobile repairing, garment making have been adversely affected during the last three decades.

\section{Conclusion}

Present study clearly reveals that there is a high variation in literacy rate, educational attainment and other indicators of education and in work participation rate, as well as across the religious communities in India. A very high inequality in literacy rates, educational attainment, mean years of schooling and high dropout rate among the minorities clearly reveal the inadequacies of India's economic growth to properly addressing the social dimensions of human development. Compared to all other religious communities, Muslims remained the most backward as far as various educational parameters are concerned. The disparities in the work participation rate were also serious between male and females as well as religious communities. Female work participation rate was considerably low as compared to male work participation rate among all the religious communities especially Muslims. Among religious communities, Muslims recorded the lowest work participation rates. They are highly engaged in unorganized sector. Thus, the backwardness of religious minorities especially Muslims-the largest minority in India indicates that the policies for the economic development could not benefit them like other groups. Therefore, they remained underdeveloped and backwards in almost all indicators of social, economic and human development. It is therefore suggested that development policies in India should be inclusive of religious minorities so that the huge inequalities can be reduced in the society.

\section{References}

India Human Development Report 2011 (2011), Towards Social Inclusion, Institute of Applied Manpower Research, Planning Commission, Government of India. 
International Journal of Social Science and Economic Research

ISSN: 2455-8834

Volume:06, Issue:07 "July 2021"

Panagariya, A. and More, V. (2013), Poverty by Social, Religious \& Economic Groups in India and its Largest States 1993-94 to 2011-12, Working Paper No. 2013-02, Program on Indian Economic Policies, Columbia University, in the City of New York.

Papola, T. S. (2012), Social Exclusion and Discrimination in the Labour Market, Working Paper 2012/04, Institute for Studies in Industrial Development (ISID), New Delhi.

Planning Commission (2011), Faster, Sustainable and More Inclusive Growth: An Approach to the Twelfth Five Year Plan, Government of India.

Planning Commission (2012), Report of the Expert Group to Recommend the Detailed Methodology for Identification of Families Living below Poverty Line in the Urban Areas, Perspective Planning Division, Government of India.

Sachar Committee Report (2006), Social, Economic and Educational Status of the Muslim Community of India, Prime Minister's High Level Committee, Cabinet Secretariat, Government of India.

Shariff, A. S. (2013), Six Years after Sachar: Review of Socially Inclusive Policies in India Since 2006, Executive Summary of USIPI Special Report No. 1, US-India Policy Institute, Washington D. C., USA.

United Nations Development Programme (2010), Marginalised Minorities in Development Programming: A UNDP Resource Guide and Toolkit, UNDP, New York, USA. 